\section{SOI: 1.1/TAS DOI: 10.15863/TAS International Scientific Journal Theoretical \& Applied Science}

p-ISSN: 2308-4944 (print) e-ISSN: 2409-0085 (online)

Year: $2018 \quad$ Issue: 03 Volume: 59

Published: $20.03 .2018 \quad$ http://T-Science.org
Vasila Karimbekovna Abdullaeva

Doctor of sciences in medicine, Head of Department of psychiatry and medical psychology

Tashkent pediatric medical institute, Uzbekistan

Anastasiya Alexsandrovna Matveeva Assistant of Department of psychiatry and medical psychology

Tashkent pediatric medical institute, Uzbekistan

SECTION 20. Medicine.

\title{
CLINICAL AND PSYCHOLOGICAL FEATURES OF PRE-SUICIDAL PERIOD OF SUICIDES
}

Abstract: To study the peculiarities of the presuicidal period and the personal characteristics of suicides, 36 patients admitted to the city clinical psychiatric hospital in Tashkent in connection with the suicide attempt were examined by clinical psychopathological method. The revealed personal characteristics of suicides determine a high probability of occurrence of disadaptation disorders, which are the source of suicidal behavior.

Key words: suicide, suicidal behavior, personality features

Language: English

Citation: Abdullaeva VK, Matveeva AA (2018) CLINICAL AND PSYCHOLOGICAL FEATURES OF PRE-SUICIDAL PERIOD OF SUICIDES. ISJ Theoretical \& Applied Science, 03 (59): 141-143.

Soi: http://s-o-i.org/1.1/TAS-03-59-22 Doi: crostef https://dx.doi.org/10.15863/TAS.2018.03.59.22

\section{Introduction}

Suicidal behavior, due to the severity of medical, socio-psychological and economic consequences are classified as not only general medical, but also global problems of humanity. Suicidal behavior is a manifestation of suicidal activity. It includes suicidal thoughts, intentions, statements, threats, suicidal attempts and attempts.

According to $\mathrm{WHO}$, the suicide rate in the world has increased by $60 \%$ over the past 45 years. The highest suicide risk is in Eastern Europe, where the suicide rate varies from 3.8 to 40 per 100,000 population [1, p. 34].

According to numerous sample studies, the number of male suicides per female suicide varies from 3 to 8 [2, p. 59]. In patients of general practice, the frequency of suicidal thoughts is 1 (for the last week) - 10\%, but more often in mentally (depressive) and somatically (heart disease, gastric ulcer) patients suffering from physical diseases $[5, \mathrm{p}$. 46]. Suicidal thoughts are connected with the deterioration of the medical prognosis: with an increase of $23 \%$ in the risk of non - suicidal mortality, mainly due to cardiovascular diseases, over the next 17 years after the control of demographic variables, bodily health, symptoms of depression and anxiety, possible dementia [11, p. 22].

Taking into account the number of failed suicides, which occur 20 times more often, the scale of the problem increases even more [3, p. 437; 10 , p.
63]. The level of suicide among persons with serious mental illness, higher than the suicide rate in the General population is 2.5 to 5 times [4, p. 35; 7, p. 22]. The percentage of detected affective disorders among suicides ranges from 70 to $80 \%$ [9, p. 30]. Features of the mental state of persons who have made suicidal attempts are the subject of research of scientists, practitioners, sociologists, psychologists, psychiatrists.

Suicidal acts are usually planned and carried out alone. The reaction of this type is characteristic of mature persons over 40 years of age, in which suicide is usually committed expressed depression. It should be noted that the majority of suicides in the early stages of suicidal behavior there is a state of fighting motives: on the one hand, there are suicidal motives, on the other - there are thoughts about the obligations to children, unwillingness to bring grief to relatives, fear of death and other holding a person from committing a suicide act motives. In other words, suicides are struggling with suicidal and antisuicidal motives, and the more pronounced the latter, the less likely it is to be suicidal.

Stressful life events at a critical moment of development reveal a predisposition to suicidal behavior. Interpersonal (family) disorder, money and production problems, violations of the law are common for young suicides, but chronic painful disabling bodily ailments, serious losses (life partner, particularly sudden) - typical distresses a weekmonths before suicidal behavior of elderly [6, p. 
401]. Often the problems are chronic, cumulated, men are more vulnerable [8, p. 310].

The aim of the study was to study the features of the presuicidal period and the personality characteristics of suicides.

\section{Material and methods:}

Clinical and psychopathological method examined 36 patients admitted to the city clinical psychiatric hospital in Tashkent in connection with the suicide attempt. The mean age of the examined patients was $34.4 \pm 2.3$ years. Assessment of mental status was carried out in the post-suicidal period and the reconstruction of the pre-suicidal period. Holms and RAE methods were used to determine stress resistance and social adaptation of suicides.

Depressive disorders are differentiated according to the type of a host affect. The survey results were supplemented by an analysis of standardized psychometric scales - scale Montgomery-Asberg (MADRS) to assess the level of depression, scales of self-esteem level of situational and personality anxiety Spielberger Ch.D. - Hanin Yu.L., questionnaire Smisek-Leongard, methods for determining the level of subjective control (UIC). The peculiarities of psychological protection mechanisms were studied using the PlutchikKellerman-Konte method.

\section{Results and discussion:}

The analysis of background factors preceding the development of depression revealed psychopathologically burdened inheritance in $28 \%$ of patients, with the most frequent diseases of close relatives were affective disorders of various genesis and alcoholism. Premorbid personal characteristics of patients with depressive disorders were sufficiently pronounced, which allowed them to be attributed to explicit character accentuations with a predominance of inhibitable $(27.2 \%)$ and cycloidal traits $(15.8 \%)$.

Eating disorders were observed in $57.9 \%$ of patients. Appetite reduction was often combined with some gastrointestinal disorders: heartburn, flatulence, constipation, diarrhea. In some cases, a clear reduction in appetite was not enough, but patients talked about the lack of pleasure from eating. Sleep disorders in patients were observed in $71 \%$ of cases. The most frequent difficulty falling asleep since seizing representations or exhausting inner dialogue, night and early awakening, shallow sleep with anxious dreams. There was also a dream with a sense of continuous thought work as well as a feeling of complete lack of sleep - a kind of phenomenon, which we have identified as "agnosia" sleep. Lack of energy or fatigue ranked second after depressed mood $(79.4 \%)$. Patients usually complain of fatigue, weakness, fragility, unwillingness to do anything, reduced performance. The sense of weakness that is perceived by patients as a fairly severe violation of the usual sensations of your body begin to occur hypochondriac fears, phobic reaction, obsessive doubts. Low self-esteem were found in $62.5 \%$ of cases and most often concerned cognitive capabilities, ability to work, physical strength and energy. Was noted secondary to the idea of guilt that arise transiently in connection with the jet experiencing life circumstances. Disturbance of concentration or difficulty in decision-making was observed in $50.5 \%$ of patients. Complaints were the lack or loss of memory, difficulty in focusing, lack of volitional activity.

When determining stress resistance and social adaptation with the help of Holmes-RAE method, the sum of the points of vital events experienced by suicides was calculated. The majority of suicides (by $78.2 \%$ ) resistance to stress was to the threshold or lower. The number of points in women and men did not differ significantly. This confirms the subjective perception of stressful events and maladjustment relative to each suicide.

Affective-tensioned type presuicidal defined in $90.2 \%$ of cases (mostly patients with neurotic and personality disorders, organic brain damage). Affective-reduced version of presuicidal met in $9.8 \%$ of patients, mainly with endogenous mental disorders.

The duration of pre-suicidal period was uneven: chronic pressuized is $58.4 \%$, acute pressuized of $38.5 \%$, subacute pressuized is $3.1 \%$.

Almost all patients who made suicidal attempts, testified to the inability to manage their desires. Precisely the absence of control over suicidal thoughts remains ready has led to transition from domestic forms of suicidal to targeted action.

The study was studied the personal characteristics of suicides. With the help of questionnaire Smisek-Leongard of suicides revealed the predominance of such traits as emotively (18.3\%), cyclothymia $(15.9 \%)$, anxiety (15.1 per cent). For men was typical of cyclothymia $(30.2 \%)$ and anxiety (25.4\%), and for women - emotively $(42.9 \%)$, anxiety $(31.7 \%)$, cyclothymia $(27.8 \%)$ and exaltation $(23.0 \%)$.

A method for determining the level of subjective control has allowed to reveal significant predominance of the externality factor in all spheres of activities of subjects that speaks about loss by the person of control over their actions. Among the types of psychological protection by the method of Plutchik-Kellerman-Konte prevailed: projection $(61,1 \%)$, reactive formations $(60,3 \%)$ and rationalization $(57,3 \%)$. Regression $(34.3 \%)$ and substitution (26.7\%) were less common. The revealed distribution of types of psychological protection explains the direction of aggressive trends in suicidal behavior on their own personality. 
The use of the scale Spilberger Ch.D. - Hanina Yu.L. showed that among men more often there was moderate, and in women - a high level of personal anxiety in the prevalence of high rates of situational anxiety in both sexes. With mild and moderate depression, predominantly moderate personal anxiety was recorded. Severe depression was represented by high and moderate levels. Consequently, the increase in the severity of depressive disorder leads to an increase in the level of personal anxiety and increases the risk of suicide.

Indicators of the level of situational anxiety were equally represented by a high and moderate degree, regardless of the severity of depressive symptoms. The high level of situational anxiety prevented the severity of suicidal act, increased suicidal activity in general, that is, responsible for the speed of autoagressive response to the situation, regardless of the severity of depressive disorder.
Thus, situational anxiety, in contrast to trait anxiety, reduces the severity of suicidal intent, but increases the likelihood of self-injurious, including demonstration activities. It should be noted that the most often high rates of personal and situational anxiety were found in patients with schizophrenia.

\section{Conclusions:}

Thus, the personal characteristics of suicides were characterized by violation of communication abilities, inadequate self-regulation, high degree of personal and situational anxiety, prevalence of unproductive methods of psychological protection and structure of agressiveness, low or threshold resistance to stress (78.2\% of suicides), which determines the high probability of disadaptation disorders, which are the source of suicidal behavior.

\section{References:}

1. Agafonov SK (2005) Analiz dinamiki suicidov v Rostovskoy oblasti za period 1993-2003gg. // Materiali XIV sezda psihiatrii Rossii, p. 34.

2. Vaulin SV, Alekseeva MV (2007) Depressivnie rasstroystva I suicidalnost (patogeneticheskiy aspect) // Vestnik Smolenskoy medicinskoy akademii № 3, pp. 58-60.

3. Gladishev MV, Polojiy BS (2005) Suicidalnoe povedenie bolnih $\mathrm{s}$ psihicheskimi rasstroystvami // Materiali XIV sezda psihiatrov Rossii M, p. 437.

4. Jenkins R, Kovess V (2002) Evaluation of suicide prevention: a European approach // International review of psychiatry, Vol. 14, № 1, pp. 34-41.

5. Taranova EI (2011) Semy kak factor, vliyayutchiy na formirovanie autoagressivnogo, suicidalnogo povedeniya $\mathrm{v}$ podrostkovom vozraste// Nauchnie vedomosti BelGU. Seriya Vtdicina. Farmacia, №10, pp. 44-49

6. Evans J, Williams JM, O'Loughlin S, Howells K (1992) Autobiographical memory and problem-solving strategies of parasuicide patients // J. Psychol. Med, Vol. 22, pp. 399405.

7. Williams JM, Pollock LR (2000) The psychology of suicidal behaviour // The International Handbook of Suicide and Attempted Suicide, J.Willey \& Sons, 235 p..

8. Zaharov VE, Rozanov VA, Krivda GF, JuJulenko PN (2012) Dannie monitoring suicidalnih popitok I zavershennih suicidov $\mathrm{v} g$. Odesse// Suicidologiya, № 4, p. 310.

9. Abramova NM (2006) Rezul'taty issledovanija lichnosti suicidentov s pomoshh'ju Jastrukturnogo testa Ammona (ISTA) // Vestnik psihiatrii i psihologii Chuvashii, № 2, pp. 2737.

10. Vaulin SV, Alekseeva MV (2007) Patogeneticheskie kredposilki terapii, diagnostiki I prevencii suicidalnogo povedeniya// Aktualnie problem sovremennoy medicine; Sbornic nauchnih trudov - Smolensk, p.63.

11. Voyceh VF (2006) Dinamika i struktura samoubiystv V Rossii // Socialnaya I klinicheskaya psihiatriya №3, p. 22. 